\title{
MINERAL NUTRITION OF YOUNG ASH IN LATVIA
}

\author{
Gunta Čekstere $^{1 \#}$, Anita Osvalde ${ }^{1}$, and Māris Laivin̨š̌̌ ${ }^{2,3}$ \\ ${ }^{1}$ Institute of Biology, University of Latvia, Miera iela 3, Salaspils, LV-2169, LATVIA \\ ${ }^{2}$ Latvian State Forest Research Institute "Silava", Rīgas iela 111, Salaspils, LV-2169, LATVIA \\ ${ }^{3}$ Forest Sector Competence Centre, Dzērbenes iela 27, Rīga, LV-1006, LATVIA \\ \# Corresponding author: guntac@inbox.lv
}

Communicated by Pēteris Zālìtis

\begin{abstract}
The research objectives were: 1) to determine healthy young ash supply with nutrients and their concentrations in natural growth conditions; 2) to estimate nutrient balance and inter-correlations within a system "soil-plants"; and 3) to determine the potential effect of environmental conditions (forest type, plant phytosociological group, soil group, etc.) on nutrient accumulation in soil and leaves of young ash. The investigation was conducted in 28 different forest sites with young ash in Latvia. The results demonstrated that young ash grows well on a wide range of site types in terms of soil composition, forest type and phytosociological tree group. Although highly heterogeneous, soil in ash stands in Latvia can provide a sufficient supply of nutrients. Therefore, the nutrient status of healthy young ash leaves can be characterized as sufficient, although low levels of $P, Z n$, and $K$ in leaves was found for most sites. Significant impact of soil group and forest type was found on nutrient composition of ash soil, while leaf nutrient concentrations were more dependent on the forest type and phytosociological tree group. The obtained results confirmed the ability of ash to accumulate nutrients within a certain range from soils of different fertility, organic matter content and soil reaction in Latvia.
\end{abstract}

Key words: Fraxinus excelsior, soil, leaves, nutrients.

\section{INTRODUCTION}

Currently, European or common ash (Fraxinus excelsior L.) is the most common broad-leaved tree species in Latvia. According to the State Forest Service data, the total area of F. excelsior stands was 13011 ha or $0.4 \%$ from the total forest area and $52 \%$ of the broad-leaved forest area in 2015. During recent years, especially at the turn of $20^{\text {th }}$ and $21^{\text {st }}$ centuries, a rapid dieback of Fraxinus excelsior forests, especially young stands, occurred due to impact of the pathogen Hymenoscyphus fraxineus, previously called Chalara fraxinea or Hymenoscyphus pseudoalbidus, in Latvia (Kēnigsvalde et al., 2010; Čekstere et al., 2013). This fungus is considered as the main reason for destruction of $F$. excelsior stands not only in Latvia, but throughout Europe (Kowalski, 2006; Jankovsky and Holdenrieder, 2009; Rytkönen et al., 2011; Keßler et al., 2012; Pautasso et al., 2013; Pliūra et al., 2011; Gross, 2014).

Currently, the dieback intensity of ash stands has decreased in Latvia; however, young stands are the most sensitive against environmental stress, and a stand can be lost even within one growing season of symptoms becoming visible (Laiviňš et al., 2016). Old or mature trees appear to be capable to withstand the disease for a relatively long time, but tend to succumb eventually after several seasons of infection (Keßler et al., 2012, Kirisits and Freinschlag, 2012).

Sufficient supply with nutrients promotes not only productivity of tree growth, but also tree tolerance to different diseases and stress conditions. Several scientists have specially noted the importance of copper, zinc, boron, calcium etc. (Bergmann, 1988; Marschner, 1995). A relevant factor for favourable tree growth is also soil reaction (Craul, 1999; Mandre et al., 2012). Young trees require supply with plant nutrients in forest stands with various plant species and clearings in eutrophic soils. Chemical analysis of soil and plant leaves are common diagnostic methods used to evaluate plant supply with nutrients. Such studies can determine precise amounts of nutrients available for plant uptake by roots from soil, deficiency or abundancy, and synergism and antagonism of chemical elements in a system "soil-plant" (Osvalde, 2011).

A wide range of optimal and average concentrations of nutrients in Fraxinus sp. leaves has been reported previously (Bergmann, 1988; Hofmeister et al., 2004; Hagen-Thorn et al., 2005; Aksoy and Demirezen, 2006; Cekstere et al., 2013; Veretennikov, 2006). There can be differences in nutrient accumulation between plant species growing in the 
same soils, as well as differences due to regional variations, sampling time, pollution etc. (Mertens et al., 2007). The results of soil studies are often also difficult to compare due to differences in soil extraction methods. Nutrient supply in young $F$. excelsior stands estimated by soil and plant chemical analysis has not been investigated sufficiently, especially in Latvia.

In Latvia, analysis of plant chemical composition has been used mainly to determine nutrient status of crop species and to develop optimal levels for nutrient concentrations in soil and plant leaves (Rinkis and Nollendorfs, 1982; Riņkis and Ramane, 1989; Rinkis et al., 1989; Osvalde and Karlsons, 2010; Osvalde et al., 2015, etc.), but less attention has been paid to optimize tree growth demands in forestry. The first data on some macro- and micronutrient concentrations in wood and leaves/needles for the most common forest tree species (pine, spruce, birch, asp, oak, ash tree, grey alder, and black alder) in Latvia were published in the middle of the $20^{\text {th }}$ century (Bambergs and Knāvina, 1950). Recently, mineral nutrient concentrations in biomass components (leaves, wood unbarked, roots) of young birch stands in different forest growing conditions and soil types were determined (Daugaviete et al., 2015). Chemical composition of spruce needles (N, P, K, Ca, Mn concentration) was also used to determine the effect of drainage ditch on edaphic conditions in mires (Janševska, 1975). Experiments with different fertilization treatments has shown a positive effect on concentrations of $\mathrm{N}, \mathrm{P}$, and $\mathrm{K}$ in needles of 13-year-old pine trees in the second year after treatment (Kāposts et al., 1979). Several studies including fertilization experiments have been conducted to evaluate growing conditions and supply with nutrients in relationship with spruce dieback and development of ectomycorrhizal fungi in mature managed forest stands and young plantations on drained peatland areas (Kḷaviṇa, 2015; Nollendorfs, unpublished).

In 2011-2012, a pilot study on mineral nutrition of young ash trees, both healthy and infected with pathogen Hymenoscyphus fraxinea, were carried out in a few sites in Latvia. Generally, the preliminary results revealed significant lower concentrations of $\mathrm{N}, \mathrm{Ca}, \mathrm{Mg}$, and $\mathrm{Cu}$ in damaged tree leaves when compared with healthy leaves, as well as a slight tendency to accumulate lower concentrations of $\mathrm{K}, \mathrm{S}$, $\mathrm{Mn}$, and $\mathrm{Zn}$ in the damaged tree leaves (Čekstere et al., 2013). Although the results of the pilot study demonstrated several problems in mineral nutrition of $F$. excelsior, it also raised various questions. Why are young ash saplings in many sites still green with high vitality and not infected by the fungus? Which soil group has better ability to provide ash with nutrients? Further research is also necessary to increase understanding of the nutrient status of healthy ash, mainly to recognize possible imbalances and to determine measures to improve tree nutrition and vitality, especially under pressure of Hymenoscyphus fraxinea infection. In the present study on mineral nutrition conditions for young ash trees in Latvia, several objectives were defined: 1) to determine healthy young ash supply with nutrients and their concentrations in natural growth conditions; 2) to estimate nu- trient balance and inter-correlations within a system "soil-plants"; and 3) to determine the potential effect of environmental conditions (forest type, plant phytosociological group, soil group, etc.) on nutrient accumulation in soil and leaves of young ash.

\section{MATERIALS AND METHODS}

Study sites. The study was conducted in 28 sites located in different areas of Latvia (Fig. 1, Table 1). Soil and leaf samples were collected from the sites, which were placed in four forest types according to Bušs (1981): dry forests in uplands -5 sites in the Oxalidosa type and 13 sites in the Aegopodiosa type; wet mineral soil forests -4 sites in the Dryopteriosa type; and drained mineral soil forests 6 sites in the Mercurialiosa mel type Samples were taken from stands with various dominant tree species. The majority of sites (6) had Betula pendula and B. pubescens as a dominant tree species, 5 stands - Alnus glutinosa and Fraxinus excelsior, 2 - Tilia cordata, Ulmus glabra, Pinus sylvestris and Acer platanoides, and 1 stand - Picea abies, Populus tremula and Alnus incana. Based on the dominant tree species the sites were classified into phytosociological tree groups: 1) dry broad-leaved (Tilia cordata, Quercus robur, Acer platanoides, Ulmus glabra); 2) wet broadleaved (Alnus glutinosa, Fraxinus excelsior); 3) early successional (Populus tremula, Alnus incana, Betula pendula, B. pubescens); and 4) conifers (Picea abies, Pinus sylvestris). The forest stands were grouped according to the age of the dominant tree species: 7 sites in 10-year-old stands (clearings); 6 - in young and medium old stands (11-40-year-old trees), 10 - premature (41-100-year-old trees), 5 - mature and over-mature stands ( $>100$-year-old trees).

Field sampling. Ash leaf and soil sampling was conducted during the first decade of August 2014. In general, the vegetation season of 2014 was long, warm and precipitation was abundant. The average temperature in August was $+17.3{ }^{\circ} \mathrm{C}$ (1.1 degree above normal) with monthly precipitation $138.7 \mathrm{~mm}$ (178\% of normal) (Data of the State Ltd Latvian Environment, Geology and Meteorology Centre). Each leaf sample consisted of 7-10 randomly collected from young healthy trees (without visual signs of Hymenoscyphus

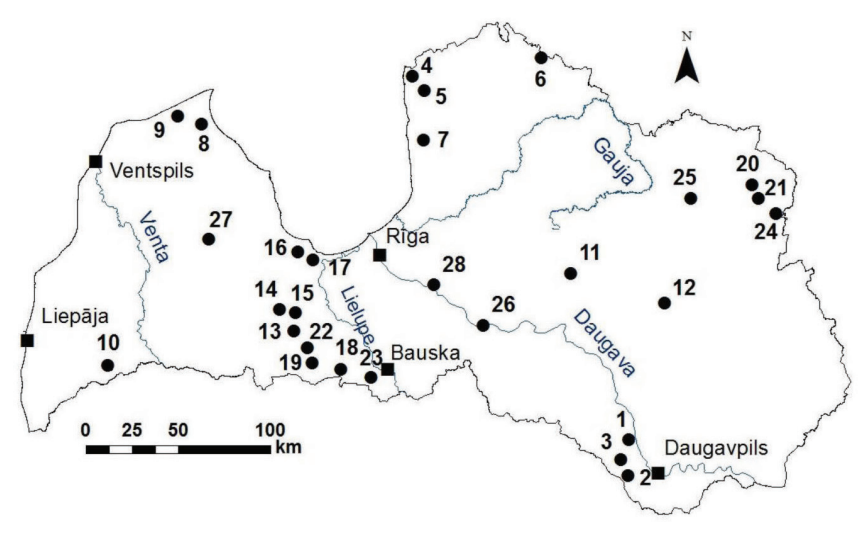

Fig. 1. Location of research sites of young ash in Latvia. 
DESCRIPTION OF THE ASH STUDY SITES IN LATVIA

\begin{tabular}{|c|c|c|c|c|c|}
\hline No. & Locality & Forest type & $\begin{array}{c}\text { Dominant species } \\
\text { in tree layer }\end{array}$ & $\begin{array}{c}\text { Age of } \\
\text { forest } \\
\text { stand } \\
\text { (years) }\end{array}$ & $\begin{array}{l}\text { Soil } \\
\text { group* }\end{array}$ \\
\hline 1 & Pilskalne & Aegopodiosa & Tilia cordata & 85 & M \\
\hline 2 & Šedere & Oxalidosa & Fraxinus excelsior & 7 & M \\
\hline 3 & Jaunlaši & Dryopteriosa & Betula pendula & 30 & M \\
\hline 4 & Ainaži 1 & Dryopteriosa & Alnus glutinosa & 5 & M \\
\hline 5 & Ainaži 2 & Mercurialiosa mel. & Ulmus glabra & 35 & $\mathrm{H}$ \\
\hline 6 & Piksāre & Aegopodiosa & Picea abies & 45 & $\mathrm{MH}$ \\
\hline 7 & Limbaži & Mercurialiosa mel. & Fraxinus excelsior & 10 & $\mathrm{MH}$ \\
\hline 8 & Vidāle & Mercurialiosa mel. & Alnus glutinosa & 55 & $\mathrm{H}$ \\
\hline 9 & Slītere & Aegopodiosa & Ulmus glabra & 110 & $\mathrm{H}$ \\
\hline 10 & Vaingode & Aegopodiosa & Fraxinus excelsior & 75 & M \\
\hline 11 & Vestiena & Oxalidosa & Fraxinus excelsior & 80 & M \\
\hline 12 & Barkava & Mercurialiosa mel. & Betula pendula & 35 & MH \\
\hline 13 & Virkus 1 & Oxalidosa & Betula pendula & 16 & M \\
\hline 14 & Virkus 2 & Oxalidosa & Pinus sylvestris & 115 & M \\
\hline 15 & Virkus 3 & Oxalidosa & Betula pendula & 70 & M \\
\hline 16 & Ķemeri 1 & Dryopteriosa & Alnus glutinosa & 90 & $\mathrm{H}$ \\
\hline 17 & Kemeri 2 & Dryopteriosa & Alnus glutinosa & 105 & $\mathrm{MH}$ \\
\hline 18 & Bērvircava & Aegopodiosa & Fraxinus excelsior & 80 & M \\
\hline 19 & Vilce & Aegopodiosa & Pinus sylvestris & 130 & M \\
\hline 20 & Vilaka 1 & Aegopodiosa & Tilia cordata & 45 & M \\
\hline 21 & Vilaka 2 & Aegopodiosa & Betula pendula & 30 & $\mathrm{MH}$ \\
\hline 22 & Zalenieki & Aegopodiosa & Populus tremula & 8 & M \\
\hline 23 & Saulaine & Aegopodiosa & Betula pendula & 10 & MH \\
\hline 24 & Aizpurve & Mercurialiosa mel. & Alnus glutinosa & 7 & $\mathrm{H}$ \\
\hline 25 & Stāmeriene & Mercurialiosa mel. & Alnus incana & 5 & MH \\
\hline 26 & Skrīveri & Aegopodiosa & Acer platanoides & 80 & M \\
\hline 27 & Abava & Aegopodiosa & Quercus robur & 180 & M \\
\hline 28 & Ogre & Aegopodiosa & Acer platanoides & 20 & M \\
\hline
\end{tabular}

*M, mineral; H, humus; MH, mineral/humus

fraxinea infection) up to $2 \mathrm{~m}$ high and 40-50 leaves without petioles. Soil samples with volume of each at least one litre were taken from 5 to $15 \mathrm{~cm}$ depth (without litter layer) and consisted of thoroughly mixed 5-7 subsamples collected by a soil probe. In each study site 3 composite samples were collected separately and analysed in the laboratory. The soils in all the study sites were characterized as mineral, humus or mineral/humus soils (Table 1).

Laboratory analysis. The chemical analysis of soil and $F$. excelsior leaf samples was conducted at the Institute of $\mathrm{Bi}$ ology of the University of Latvia. The soil samples were dried at room temperature and sieved with a $<2 \mathrm{~mm}$ mesh. The soil samples were extracted with $1 \mathrm{M} \mathrm{HCl}$ extraction in a soil-extractant mixture of 1:5. This extractant is universal and quite aggressive, and thereby characterizes not only the amount of nutrient currently available for the plant uptake from the soil, but also indicates the reserve amount of elements for the remaining vegetation season (Osvalde, 1996). Tree leaves were quickly washed with distilled water, dried at $+60{ }^{\circ} \mathrm{C}$ and ground. Plant samples were dry-ashed in concentrated $\mathrm{HNO}_{3}$ vapors and re-dissolved in $3 \% \mathrm{HCl}$ for $\mathrm{K}$, $\mathrm{P}, \mathrm{Ca}, \mathrm{Mg}, \mathrm{Fe}, \mathrm{Cu}, \mathrm{Zn}, \mathrm{Mn}$, and Mo determination.

The concentrations of $\mathrm{Ca}, \mathrm{Mg}, \mathrm{Fe}, \mathrm{Cu}, \mathrm{Zn}$, and $\mathrm{Mn}$ in soil and leaves were determined by atomic absorption spectrophotometer (Perkin Elmer AAnalyst 700) in a acetylene-air flame. The concentrations of P, Mo, N, S and B were determined by colorimetry with a spectrophotometer JENWAY 6300 (Barloworld Scientific Ltd., Gransmore Green Felstad, Dunmow, Essex, UK): $\mathrm{P}$ by ammonium molybdate in an acid-reduced medium, Mo by thiocyanate in reduced acid medium, $\mathrm{N}$ by Nesler's reagent in an alkaline medium (modified Kjeldal method), B by hinalizarine in sulfuric acid medium, and $\mathrm{S}$ by turbidimetric method with $\mathrm{BaCl}_{2}$ addition. Soil pH was measured in $1 \mathrm{M} \mathrm{KCl}$ extraction (soil-extractant mixture 1:2.5). The concentration of organic matter in the soils was determined according to Tjurin (Rinkis et al., 1987). Analytical replication was three times.

Statistical analysis. The statistical analysis of the research results was conducted using Statistica and $P C$-ORD software for multivariate analysis of ecological data, as well as RStudio. Standard errors (SE) of means were calculated. The correlation coefficients (Pearson) were calculated ( $p<$ 0.05 , significant if $r>0.374$ ). ANOVA was used to determine significant differences of chemical element concentrations between research sites. To assess relationships between the chemical composition of soil and leaves, principal component analysis (PCA) was conducted using PC-ORD Version 6 (McCune and Mefford, 1999). To determine potential effect of environmental conditions (forest type, dominant tree species, forest age, and soil texture) on nutrient accumulation in ash soil and leaves, ANOVA with a post hoc test (Tukey HSD) was conducted using Statistica. For comparison, average and optimal element concentrations are given in histograms for ash leaves (Bergmann, 1988; Nollendorfs, unpublished) deciduous tree soil (Nollendorfs, unpublished) using $1 \mathrm{M} \mathrm{HCl}$ extractions.

\section{RESULTS}

Soil. The average concentrations of nutrients and their frequency distributions in ash soil are given in Table 2 and Figure 2. The lowest variability of concentration variance was found for $\mathrm{Mo}$ and $\mathrm{K}$, and the highest for $\mathrm{Ca}$ and $\mathrm{Mg}$. The maximum soil $\mathrm{pH}$ value was almost two times higher than the minimum. The average $\mathrm{Ca}: \mathrm{Mg}$ ratio in soil was $6.39 \pm 0.69$ : 1 with range from 0.77 to $14.17: 1$. To identify associations or clusters of chemical elements in soil and leaves, correlations between element concentrations were calculated. Generally, $41.76 \%$ of the calculated correlation coefficients in ash soil were statistically significant $(p<$ 0.05); one of them (P-Mg) was negative (Fig. 3A-B). The majority of micronutrients, as well as N, P, S had 3-7 medium close and close correlations. An association between soil $\mathrm{pH}, \mathrm{Ca}$ and $\mathrm{Mg}$ content was also found. ANOVA showed that the soil group and forest type had the strongest effect on soil chemical composition, while the phyto- 
MEAN NUTRIENT CONCENTRATIONS (MG L ${ }^{-1}, 1 \mathrm{M}$ HCL EXTRACTION), PH AND ORGANIC MATTER IN HEALTHY FRAXINUS EXCELSIOR SOILS IN LATVIA IN AUGUST 2014

\begin{tabular}{lcccccccccccccc|c|c|c|c}
\hline & $\mathrm{N}$ & $\mathrm{P}$ & $\mathrm{K}$ & $\mathrm{Ca}$ & $\mathrm{Mg}$ & $\mathrm{S}$ & $\mathrm{Fe}$ & $\mathrm{Mn}$ & $\mathrm{Zn}$ & $\mathrm{Cu}$ & $\mathrm{Mo}$ & $\mathrm{B}$ & $\mathrm{pH}$ & $\mathrm{OM}$ \\
\hline Mean & 44.39 & 77.03 & 139.25 & 6062.86 & 2401.25 & 20.69 & 971.52 & 157.64 & 8.46 & 2.26 & 0.04 & 0.50 & 5.72 & 19.27 \\
$\mathrm{SE}$ & 6.29 & 8.36 & 13.47 & 1689.80 & 1229.44 & 4.01 & 182.71 & 27.71 & 1.58 & 0.24 & 0.00 & 0.08 & 0.18 & 3.70 \\
$\mathrm{~V}, \%$ & 75.03 & 57.46 & 51.17 & 147.48 & 270.93 & 102.65 & 96.47 & 93.02 & 98.76 & 56.44 & 43.60 & 80.07 & 16.63 & 101.48 \\
Minimum & 8.0 & 5.5 & 54 & 565 & 80 & 5.7 & 345 & 23 & 1.65 & 0.7 & 0.02 & 0.1 & 3.84 & 3.1 \\
Maximum & 136 & 196 & 435 & 38100 & 26400 & 120 & 5150 & 765 & 46.5 & 6 & 0.09 & 1.8 & 7.36 & 66.99
\end{tabular}

*Organic matter, \%
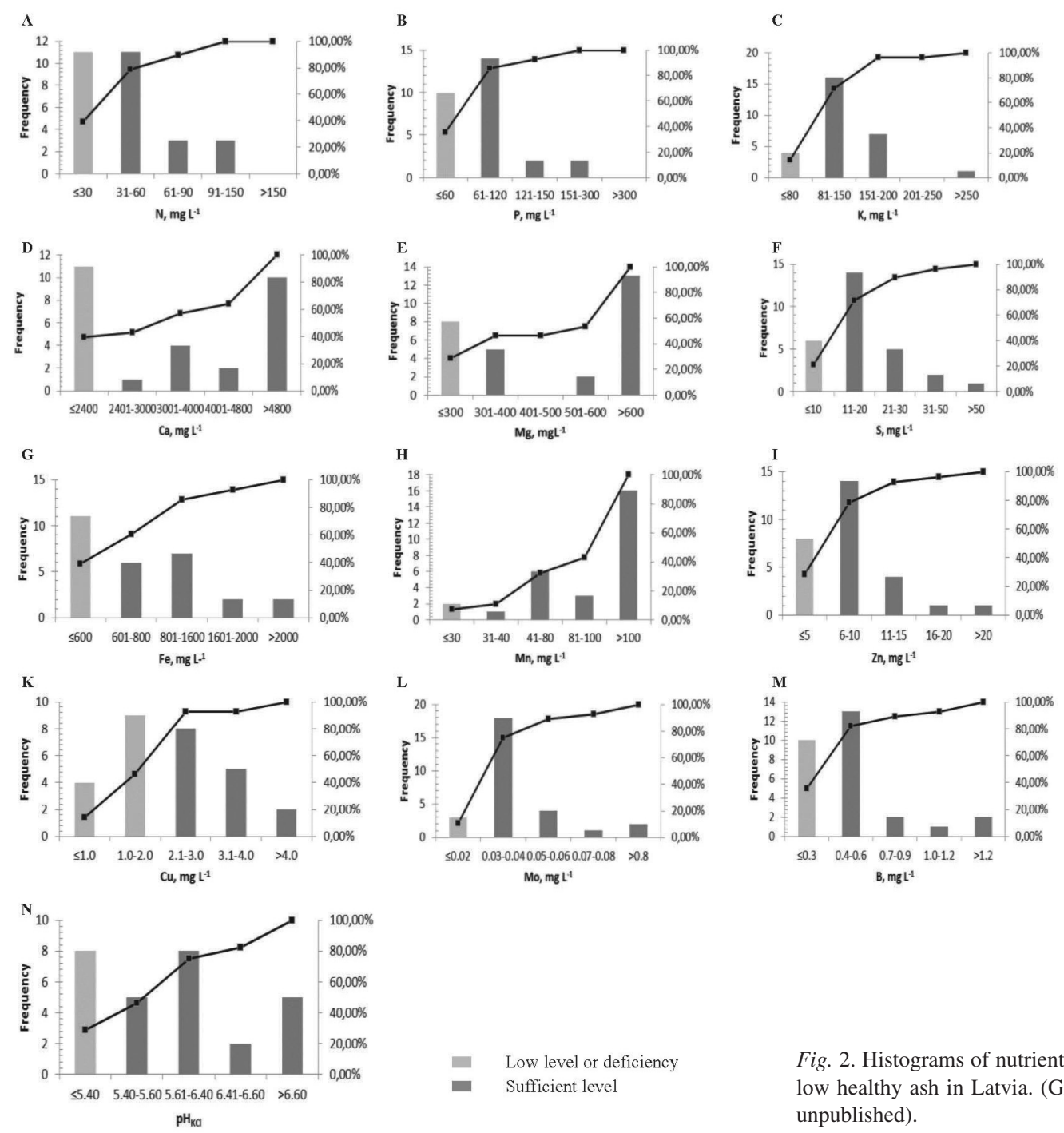

sociological tree group and forest age did not have significant effect (Table 3). Humus soils had significant higher level of $\mathrm{Mn}, \mathrm{Zn}$, and Mo compared with mineral and mineral/humus soils (Table 4), while soils from Oxalidosa forest type had the lowest content of $\mathrm{N}$ and $\mathrm{Cu}$, and Dryopteriosa and Mercurialiosa mel. had almost two-three times higher content of $\mathrm{N}$, compared with soils from other forest types (Table 5). PCA of soil chemical composition showed relatively good structure of the sampling sites in the ordination space with separation of soil group (Fig. 4A) and forest type (Fig. 4B). The first two components explained

$63.09 \%$ of the total variance and were statistically significant, $p<0.05$. The most important elements explaining gradients in the PCA were $\mathrm{Ca}, \mathrm{Mg}, \mathrm{S}, \mathrm{Fe}, \mathrm{Mn}, \mathrm{Zn}$, and $\mathrm{B}$ with eigenvector values ranging from $0.806(\mathrm{Mn})$ to 0.943 $(\mathrm{Zn})$. The $1^{\text {st }}$ axis, which explained $42.05 \%$ of the total variance, mainly separated mineral from humus soils in the ordination space. The sites affected by this factor (\#8, 12, 16, $25)$ had the closest correlations with micronutrient concentrations and the highest concentrations of $\mathrm{Fe}, \mathrm{Zn}, \mathrm{B}$. The $2^{\text {nd }}$ axis had the closest correlation with concentration of $\mathrm{Ca}$, $\mathrm{Mg}$ and also soil $\mathrm{pH}$. 


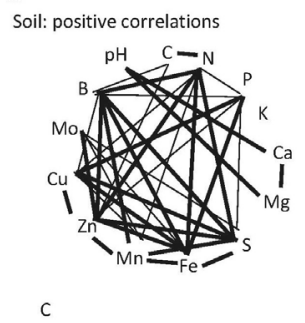

Leaves: positive correlations

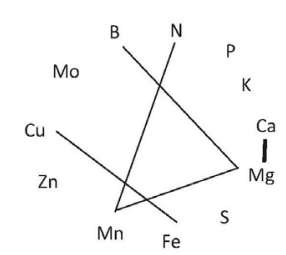

E

Soil - leaves: positive correlations

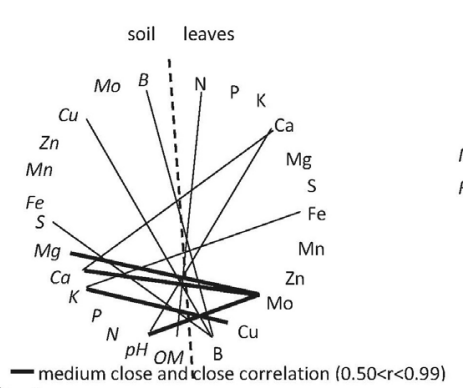

B

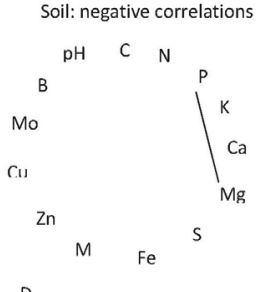

Leaves: negative correlations

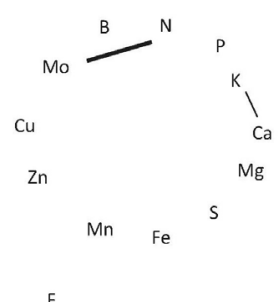

Soil - leaves: negative correlations

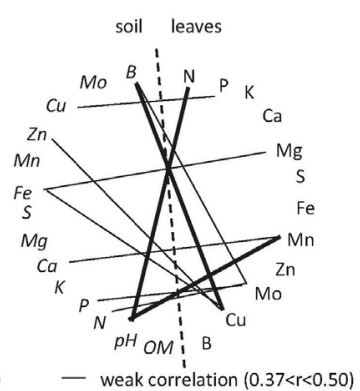

Fig. 3. Pearson's correlation coefficients between chemical element concentrations and parameters in soil and ash leaves $(\mathrm{n}=28, p<0.05, \mathrm{r}>$ 0.37; OM, organic matter).

Leaves. The nutrient concentrations in ash leaves are reported in Table 6 and Figure 5. The results showed that the lowest variability of nutrient concentrations was for B and $\mathrm{Zn}$, and the highest for $\mathrm{Mn}$ and Mo. In contrast with the results for soil, only $10.61 \%$ of the correlation coefficients between the chemical elements were statistically significant (Fig. 3C-D). The most significant correlations were between $\mathrm{Ca}$ and $\mathrm{Mg}$ (positive) and N-Mo (negative). For the system "soil-plants", $12.12 \%$ of the correlation coefficients were statistically significant; half of them were negative (Fig. 3E-F). The statistical analysis showed that the concentra-

Table 3

ANOVA TEST RESULTS OF SOIL CHEMICAL COMPOSITION FOR HEALTHY YOUNG ASH IN LATVIA

\begin{tabular}{|c|c|c|c|c|c|c|c|c|}
\hline \multirow{3}{*}{$\begin{array}{c}\text { De- } \\
\text { pendent } \\
\text { variable }\end{array}$} & \multicolumn{8}{|c|}{ Categorical factor } \\
\hline & \multicolumn{2}{|c|}{$\begin{array}{c}\text { Forest } \\
\text { type }\end{array}$} & \multicolumn{2}{|c|}{$\begin{array}{c}\text { Phytosociologic } \\
\text { al tree group }\end{array}$} & \multicolumn{2}{|c|}{ Soil group } & \multicolumn{2}{|c|}{ Forest age } \\
\hline & $\mathrm{F}^{*}$ & $\mathrm{p}$ & $\mathrm{F}^{*}$ & $\mathrm{p}$ & $\mathrm{F}^{* *}$ & $\mathrm{p}$ & $\mathrm{F}^{*}$ & $\mathrm{p}$ \\
\hline $\mathrm{N}$ & 3.940 & 0.0203 & 0.479 & 0.7001 & 12.783 & 0.0002 & 0.052 & 0.9840 \\
\hline $\mathrm{P}$ & 1.671 & 0.1997 & 1.340 & 0.2672 & 2.872 & 0.0754 & 0.112 & 0.9523 \\
\hline $\mathrm{K}$ & 1.550 & 0.2274 & 1.581 & 0.2200 & 0.431 & 0.6544 & 0.980 & 0.4186 \\
\hline $\mathrm{Ca}$ & 0.766 & 0.5244 & 2.791 & 0.0622 & 0.496 & 0.6151 & 0.342 & 0.7949 \\
\hline $\mathrm{Mg}$ & 0.837 & 0.4871 & 2.464 & 0.0868 & 0.721 & 0.4963 & 0.585 & 0.6309 \\
\hline S & 2.203 & 0.1138 & 0.318 & 0.8120 & $\mathbf{5 . 5 9 0}$ & 0.0098 & 0.588 & 0.6285 \\
\hline $\mathrm{Fe}$ & 2.919 & 0.0547 & 0.938 & 0.4376 & 4.710 & 0.0184 & 0.563 & 0.6446 \\
\hline $\mathrm{Mn}$ & 1.402 & 0.2665 & 0.834 & 0.4882 & 3.441 & 0.0478 & 2.229 & 0.1108 \\
\hline $\mathrm{Zn}$ & 2.907 & 0.0554 & 1.628 & 0.2091 & 8.809 & 0.0013 & 0.851 & 0.4799 \\
\hline $\mathrm{Cu}$ & 3.176 & 0.0424 & 0.557 & 0.6485 & 3.025 & 0.0666 & 0.952 & 0.4311 \\
\hline Mo & 0.046 & 0.9867 & 0.222 & 0.8806 & 6.353 & 0.0059 & 1.015 & 0.4032 \\
\hline B & 3.894 & 0.0212 & 1.714 & 0.1909 & 6.373 & 0.0058 & 1.155 & 0.3474 \\
\hline $\mathrm{pH}$ & 0.468 & 0.7071 & 0.719 & 0.5503 & 0.862 & 0.4346 & 0.719 & 0.5503 \\
\hline $\begin{array}{l}\text { Org. } \\
\text { matter }\end{array}$ & 5.845 & 0.0038 & 0.739 & 0.5394 & 90.045 & 0.0000 & 0.033 & 0.9916 \\
\hline
\end{tabular}

* F critical $(\mathrm{n}=28, \mathrm{Df}=3, p \leq 0.05)=2.947$, significant in bold

$* * \mathrm{~F}$ critical $(\mathrm{n}=28, \mathrm{Df}=2, p \leq 0.05)=3.340$, significant in bold

tions of several nutrients in ash leaves was significantly related with forest type and phytosociological tree group, while forest age and soil group did not have a significant effect (Table 7). Ash leaves from the Oxalidosa forest type had a significantly higher level of $\mathrm{P}$, and the Aegopodiosa had higher $\mathrm{S}$ and $\mathrm{Cu}$ concentrations, compare with the other forest types (Table 8). Ash leaves collected in the dry-broad leaved forests had the highest mean level of Mo, in conifers and dry-broad leaved forests - $\mathrm{Zn}$, and generally lower level of $\mathrm{Mg}$ was found in the wet-broad leaved forests, in comparison with the other phytosociological tree groups (Table 9). The PCA of chemical composition of ash leaves demonstrated good structure of the sites in ordination space according to forest type and phytosociological tree group; the first two components explained $43.37 \%$ of the total vari-

Table 4

NUTRIENT CONCENTRATIONS (MG L ${ }^{-1}, 1 \mathrm{M}$ HCL EXTRACTION) FOR DIFFERENT SOIL GROUPS IN HEALTHY YOUNG ASH STANDS IN LATVIA

\begin{tabular}{|c|c|c|c|c|c|c|c|}
\hline Soil group & $\mathrm{N}$ & $\mathrm{S}$ & $\mathrm{Fe}$ & $\mathrm{Mn}$ & $\mathrm{Zn}$ & Mo & B \\
\hline \multicolumn{8}{|l|}{ Mineral } \\
\hline Mean \pm SE & $26.76 \pm 4.02 \mathrm{a}^{*}$ & $13.31 \pm 1.79 \mathrm{a}$ & $651.77 \pm 68.65 a$ & $130.9 \pm 16.1 \mathrm{a}$ & $5.39 \pm 0.51 \mathrm{a}$ & $0.041 \pm 0.004 \mathrm{~b}$ & $0.34 \pm 0.05 \mathrm{a}$ \\
\hline Range & $8-56$ & $5.7-35$ & $345-1310$ & $30-265$ & $1.65-9.50$ & $0.02-0.09$ & $0.1-0.7$ \\
\hline \multicolumn{8}{|l|}{ Humus } \\
\hline Mean \pm SE & $87.20 \pm 17.05 b$ & $44.80 \pm 19.06 b$ & $1995.0 \pm 838.3 b$ & $299.0 \pm 129.4 b$ & $19.70 \pm 6.90 \mathrm{c}$ & $0.060 \pm 0.009 \mathrm{c}$ & $0.98 \pm 0.30 b$ \\
\hline Range & $38-136$ & $15-120$ & $495-5150$ & $80-765$ & $9.5-46.5$ & $0.3-0.09$ & $0.3-1.8$ \\
\hline \multicolumn{8}{|l|}{ Mineralhumus } \\
\hline Mean \pm SE & $58.67 \pm 11.65 b$ & $21.50 \pm 2.62 \mathrm{~b}$ & $1167.5 \pm 301.1 b$ & $115.7 \pm 41.8 \mathrm{a}$ & $7.82 \pm 1.49 \mathrm{~b}$ & $0.028 \pm 0.003 \mathrm{a}$ & $0.57 \pm 0.12 b$ \\
\hline Range & $30-109$ & $15-30$ & $420-2450$ & $23-305$ & $2.4-12.5$ & $0.02-0.04$ & $0.2-1.0$ \\
\hline
\end{tabular}

* Means annotated with different letters $(\mathrm{a}, \mathrm{b})$ were significantly different $(\mathrm{t}$-test, $p<0.05)$ between soil groups 
Table 5

NUTRIENT CONCENTRATIONS (MG L ${ }^{-1}, 1 \mathrm{M}$ HCL EXTRACTION) IN SOILS FROM DIFFERENT FOREST TYPES WITH HEALTHY YOUNG ASH IN LATVIA

\begin{tabular}{lccc}
\hline \multicolumn{1}{c}{ Forest type } & $\mathrm{N}$ & $\mathrm{Cu}$ & $\mathrm{B}$ \\
\hline Aegopodiosa & & & \\
Mean \pm SE & $36.85 \pm 7.88 \mathrm{~b}^{*}$ & $2.04 \pm 0.24 \mathrm{~b}$ & $0.32 \pm 0.06 \mathrm{a}$ \\
Range & $10.00-109$ & $0.70-3.60$ & $0.10-0.70$ \\
Oxalidosa & & & \\
Mean \pm SE & $17.40 \pm 5.28 \mathrm{a}$ & $1.23 \pm 0.14 \mathrm{a}$ & $0.42 \pm 0.04 \mathrm{a}$ \\
Range & $8-38$ & $0.9-1.5$ & $0.3-0.5$ \\
Dryopteriosa & & & \\
Mean \pm SE & $64.50 \pm 16.40 \mathrm{c}$ & $3.10 \pm 0.89 \mathrm{~b}$ & $0.93 \pm 0.32 \mathrm{~b}$ \\
Range & $43-113$ & $1.35-5.50$ & $0.40-1.80$ \\
Mercurialiosa mel. & & & \\
Mean \pm SE & $69.83 \pm 14.82 \mathrm{c}$ & $3.05 \pm 0.65 \mathrm{~b}$ & $0.70 \pm 0.19 \mathrm{~b}$ \\
Range & $38-136$ & $1.45-0.60$ & $0.3-1.6$ \\
\hline
\end{tabular}

*Means annotated with different letters $(\mathrm{a}, \mathrm{b}, \mathrm{c})$ were significantly different (t-test, $p<0.05)$ between forest types.

ance (Fig. 6). The most important factors in the PCA were $\mathrm{Ca}, \mathrm{Mg}, \mathrm{K}, \mathrm{Mo}$, and $\mathrm{B}$ with eigenvector values ranging from $0.633(\mathrm{Mg})$ to 0.729 (B). However, each forest type and phytosociological tree group showed relatively wide variance of chemical composition. For example, most leaf samples from the Aegopodiosa forests were mainly located on the left side in the ordination space in the direction of nutrient vectors, while some occurred on the opposite side. Chemical composition was most similar between ash leaf samples from Oxalidosa and Mercurialiosa mel. stands (Fig. $6 \mathrm{~A})$. The most pronounced differences in leaf chemical composition occurred between ash leaves collected in the dry broad-leaved forests (Quercus robur, Tilia cordata, Acer platanoides, Ulmus glabra) and the wet broad-leaved forests (Fraxinus excelsior, Alnus glutinosa, Alnus incana) (Fig. 6B), indicating that young ash trees in the dry broad-leaved forests had higher concentrations of nutrients in leaves compared with the other phytosociology groups of forests.

\section{DISCUSSION}

Soil. Ash is mesophilic and has relatively high requirement for nutrients (Diekmann, 1996; Pliūra and Heuertz, 2003, Kerr and Cahalan, 2004; Fraxigen, 2005; Dobrowolska et
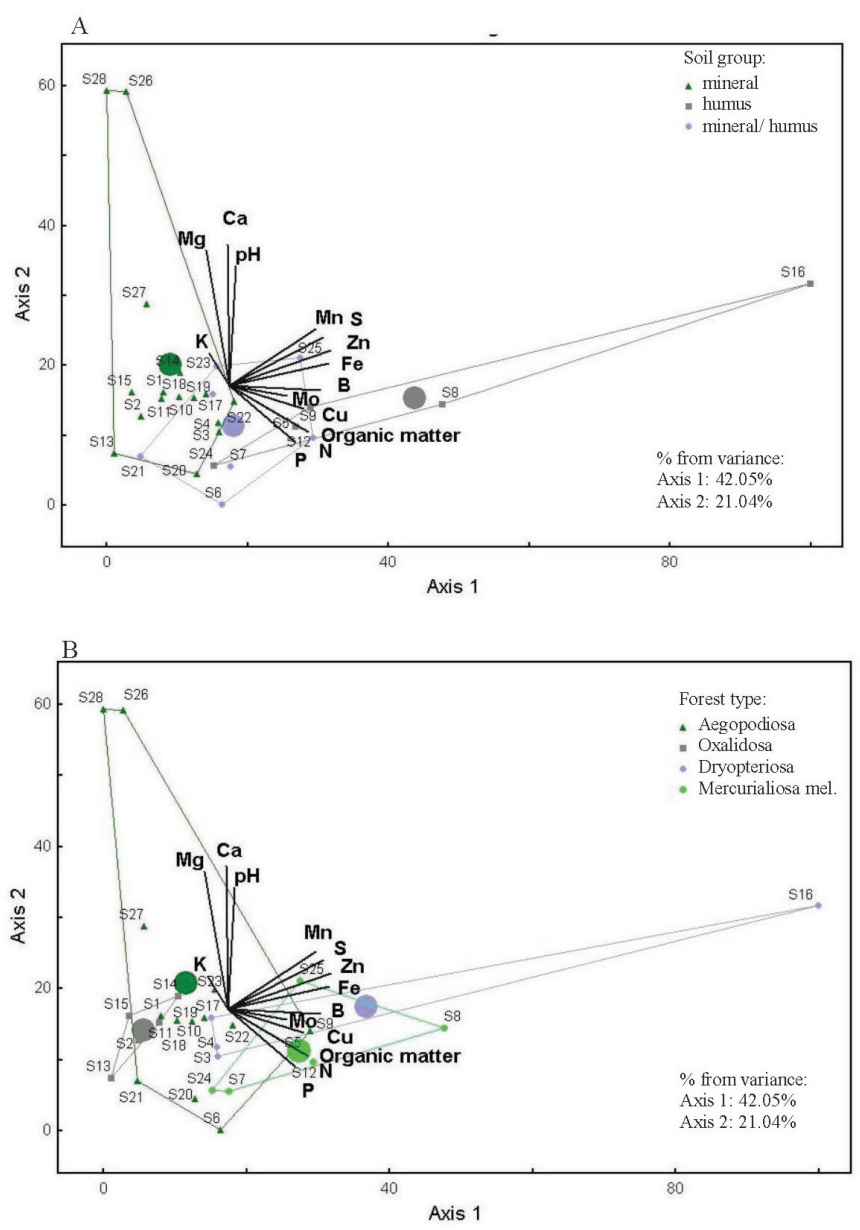

Fig. 4. Principal component analysis of chemical composition of soils below healthy ash in Latvia.

al., 2011); however, it is also found in a vast range of growing conditions from nutrient rich to poorer soils (Pautasso et al., 2013). Although the analysed ash soils on average can be characterised as sufficient or almost sufficient with most nutrients, the results presented in the histograms show that $30-40 \%$ of the studied soil sites might have a low level or deficiency in one or more elements, mainly $\mathrm{N}, \mathrm{P}, \mathrm{Ca}, \mathrm{Fe}$, or $\mathrm{B}$. The mean results on micronutrient content were in good agreement with previous research on nutrient status of young ash stand (Cekstere et al., 2013), while macronutrient $(\mathrm{N}, \mathrm{P}, \mathrm{K})$ concentrations obtained in this study were lower compared with the previous results on concentrations of these elements in healthy and damaged ash tree soil in Latvia.

Table 6

MEAN NUTRIENT CONCENTRATIONS IN HEALTHY YOUNG FRAXINUS EXCELSIOR LEAVES IN LATVIA IN AUGUST 2014

\begin{tabular}{|c|c|c|c|c|c|c|c|c|c|c|c|c|}
\hline & $\mathrm{N}$ & $\mathrm{P}$ & $\mathrm{K}$ & $\mathrm{Ca}$ & $\mathrm{Mg}$ & $S$ & $\mathrm{Fe}$ & $\mathrm{Mn}$ & $\mathrm{Zn}$ & $\mathrm{Cu}$ & Mo & B \\
\hline & \multicolumn{6}{|c|}{$\%$} & \multicolumn{6}{|c|}{$\mathrm{mg} \cdot \mathrm{kg}^{-1}$} \\
\hline Mean & 2.46 & 0.16 & 1.07 & 2.24 & 0.80 & 0.28 & 117.00 & 61.86 & 17.10 & 7.44 & 0.55 & 19.64 \\
\hline $\mathrm{V}, \%$ & 18.84 & 24.67 & 27.36 & 21.17 & 22.94 & 21.05 & 48.13 & 64.67 & 13.28 & 21.11 & 74.56 & 9.62 \\
\hline Minimum & 1.32 & 0.10 & 0.54 & 1.01 & 0.37 & 0.17 & 56 & 20 & 13.20 & 4.40 & 0.20 & 16 \\
\hline Maximum & 3.30 & 0.24 & 1.76 & 3.14 & 1.21 & 0.40 & 276 & 190 & 24.00 & 11.60 & 1.80 & 24 \\
\hline
\end{tabular}



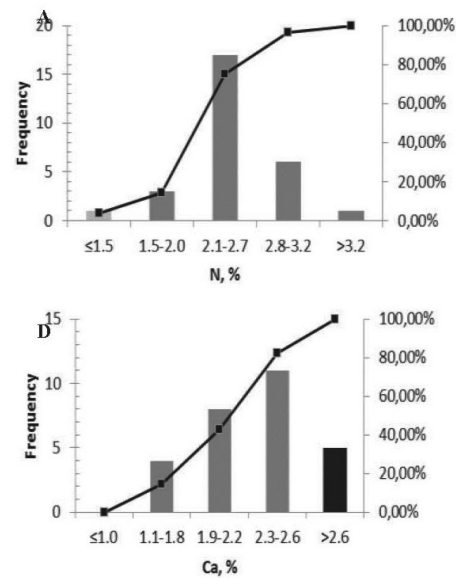

Ca, \%
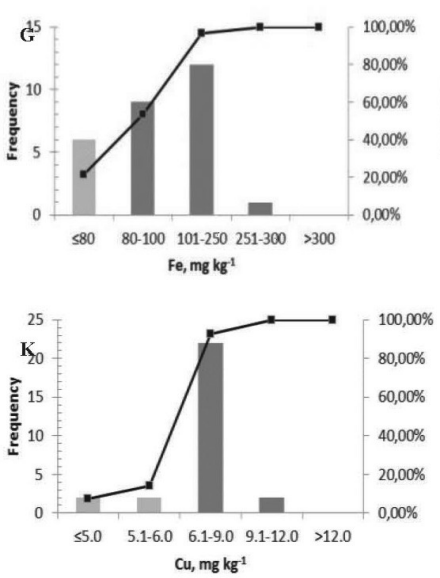

Low level or deficiency
- Sufficient level
High level

Table 7

ANOVA RESULTS FOR CHEMICAL COMPOSITION OF HEALTHY YOUNG ASH LEAVES IN LATVIA

\begin{tabular}{|c|c|c|c|c|c|c|c|c|}
\hline \multirow{3}{*}{$\begin{array}{c}\text { De- } \\
\text { pendent } \\
\text { variable }\end{array}$} & \multicolumn{8}{|c|}{ Categorical factor } \\
\hline & \multicolumn{2}{|c|}{$\begin{array}{l}\text { Forest } \\
\text { type }\end{array}$} & \multicolumn{2}{|c|}{$\begin{array}{c}\text { Phytosociologic } \\
\text { al tree group }\end{array}$} & \multicolumn{2}{|c|}{ Soil group } & \multicolumn{2}{|c|}{ Forest age } \\
\hline & $\mathrm{F}^{*}$ & $\mathrm{p}$ & $\mathrm{F}^{*}$ & $\mathrm{p}$ & $\mathrm{F}^{* *}$ & $\mathrm{p}$ & $\mathrm{F}^{*}$ & $\mathrm{p}$ \\
\hline $\mathrm{N}$ & 2.645 & 0.0721 & 0.639 & 0.5972 & 2.134 & 0.1394 & 1.042 & 0.3919 \\
\hline $\mathrm{P}$ & 0.031 & 0.0123 & 1.053 & 0.3875 & 1.880 & 0.1735 & 0.092 & 0.9639 \\
\hline K & 1.012 & 0.4049 & 2.578 & 0.0773 & 0.635 & 0.5382 & 0.485 & 0.6958 \\
\hline $\mathrm{Ca}$ & 0.818 & 0.4966 & 0.978 & 0.4194 & 0.866 & 0.8663 & 1.827 & 0.1691 \\
\hline $\mathrm{Mg}$ & 2.418 & 0.0910 & 4.213 & 0.0158 & 1.227 & 0.3102 & 2.236 & 0.0704 \\
\hline S & 4.692 & 0.0102 & 2.629 & 0.0733 & 0.544 & 0.5874 & 1.207 & 0.3284 \\
\hline $\mathrm{Fe}$ & 3.013 & 0.0498 & 2.617 & 0.0742 & 0.070 & 0.9325 & 1.138 & 0.3536 \\
\hline $\mathrm{Mn}$ & 0.471 & 0.6993 & 1.138 & 0.3538 & 0.194 & 0.8246 & 1.970 & 0.1454 \\
\hline $\mathrm{Zn}$ & 0.212 & 0.8874 & 3.017 & 0.0496 & 0.670 & 0.5204 & 2.247 & 0.1087 \\
\hline $\mathrm{Cu}$ & 4.991 & 0.0079 & 1.839 & 0.1670 & 0.782 & 0.4684 & 0.240 & 0.8675 \\
\hline Mo & 2.407 & 0.0921 & 3.249 & 0.0394 & 1.380 & 0.2702 & 0.0390 & 0.9894 \\
\hline B & 2.344 & 0.0983 & 1.091 & 0.3720 & 0.170 & 0.8449 & 0.358 & 0.7842 \\
\hline
\end{tabular}

$*$ F critical $(\mathrm{n}=28, \mathrm{df}=3, p \leq 0.05)=2.947$, significant in bold

** F critical $(\mathrm{n}=28, \mathrm{df}=2, p \leq 0.05)=3.340$, significant in bold

The wide range of soil $\mathrm{pH}$ value revealed that healthy young ash in Latvia grew both in soil with acid and neu-
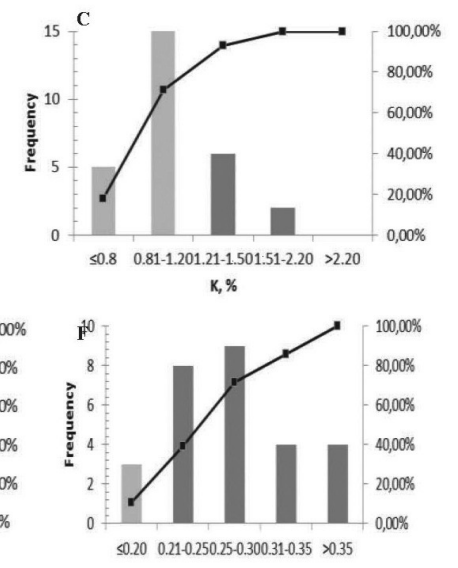

$5, \%$
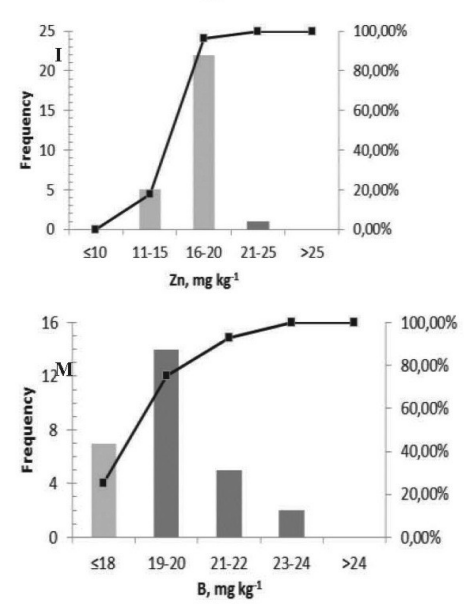

Fig. 5. Histograms of nutrient concentrations for healthy ash leaves in Latvia. (Graduation compiling Nollendorfs (unpublished) and Bergmann (1988)).

Table 8

MEAN NUTRIENT CONCENTRATIONS ( \pm SE) IN HEALTHY YOUNG ASH LEAF SAMPLES IN LATVIA IN AUGUST 2014 ACCORDING TO FOREST TYPE

\begin{tabular}{lccc}
\hline Forest type & $\mathrm{P}, \%$ & $\mathrm{~S}, \%$ & $\mathrm{Cu},{\mathrm{mg} \cdot \mathrm{kg}^{-1}}^{-}$ \\
\hline $\begin{array}{c}\text { Aegopodiosa } \\
\text { Mean } \pm \mathrm{SE}\end{array}$ & $0.15 \pm 0.01 \mathrm{a} *$ & $0.32 \pm 0.02 \mathrm{~b}$ & $8.26 \pm 0.38 \mathrm{~b}$ \\
Range & $0.11-0.21$ & $0.20-0.40$ & $6.00-11.60$ \\
Oxalidosa & & & \\
Mean $\pm \mathrm{SE}$ & $0.20 \pm 0.02 \mathrm{~b}$ & $0.25 \pm 0.02 \mathrm{a}$ & $6.64 \pm 0.55 \mathrm{a}$ \\
Range & $0.14-0.24$ & $0.17-0.29$ & $5.2-8.60$ \\
Dryopteriosa & & & \\
Mean \pm SE & $0.13 \pm 0.02 \mathrm{a}$ & $0.27 \pm 0.02 \mathrm{a}$ & $5.60 \pm 0.61 \mathrm{a}$ \\
Range & $0.10-0.18$ & $0.21-0.30$ & $4.40-7.00$ \\
Mercurialiosa mel. & & & \\
Mean \pm SE & $0.15 \pm 0.01 \mathrm{a}$ & $0.24 \pm 0.01 \mathrm{a}$ & $7.57 \pm 0.54 \mathrm{ab}$ \\
Range & $0.10-0.18$ & $0.17-0.25$ & $6.40-9.60$
\end{tabular}

*Means annotated with different letters $(a, b)$ were significantly different (t-test, $p<0.05)$ in the column.

tral/slightly alkaline reaction. However, the majority of sites had adequate soil $\mathrm{pH}$ for ash growth. Ash generally grows well on soils with a pH above 5-6 (Zollner and Kölling 1994; Pliūra and Heuertz, 2003) or prefers neutral soils 
Table 9

MEAN NUTRIENT CONCENTRATIONS ( \pm SE) IN HEALTHY FRAXINUS EXCELSIOR LEAVES IN LATVIA IN AUGUST 2014 ACCORDING TO PHYTOSOCIOLOGICAL TREE GROUP

\begin{tabular}{l|c|c|c}
\hline $\begin{array}{c}\text { Phytosociological } \\
\text { tree group }\end{array}$ & $\mathrm{Mg}, \mathrm{mg} \cdot \mathrm{kg}^{-1}$ & $\mathrm{Zn}, \mathrm{mg} \cdot \mathrm{kg}^{-1}$ & $\mathrm{Mo}, \mathrm{mg} \cdot \mathrm{kg}^{-1}$ \\
\hline $\begin{array}{c}\text { Dry broad-leaved } \\
\text { Mean } \pm \text { SE }\end{array}$ & $0.94 \pm 0.06 \mathrm{~b}^{*}$ & $18.49 \pm 1.16 \mathrm{~b}$ & $0.90 \pm 0.23 \mathrm{ab}$ \\
Range & $0.73-1.21$ & $14.60-24.00$ & $0.20-1.80$ \\
Wet broad-leaved & & & \\
Mean \pm SE & $0.68 \pm 0.05 \mathrm{a}$ & $16.40 \pm 0.52 \mathrm{a}$ & $0.37 \pm 0.05 \mathrm{a}$ \\
Range & $0.37-0.88$ & $13.20-19.00$ & $0.20-0.80$ \\
Small leaved & & & \\
Mean \pm SE & $0.83 \pm 0.06 \mathrm{~b}$ & $16.00 \pm 0.60 \mathrm{a}$ & $0.58 \pm 0.14 \mathrm{a}$ \\
Range & $0.67-1.03$ & $13.40-18.00$ & $0.20-1.30$ \\
Conifers & & & \\
Mean \pm SE & $0.85 \pm 0.03 \mathrm{~b}$ & $19.00 \pm 0.53 \mathrm{~b}$ & $0.35 \pm 0.09 \mathrm{a}$ \\
Range & $0.82-0.90$ & $18.00-19.80$ & $0.20-0.50$
\end{tabular}

* Means annotated with different letters $(\mathrm{a}, \mathrm{b})$ were significantly different (t-test, $p<0.05)$ in the column.

(Dobrowolska et al., 2011). Thus, the low pH level in several sites could negatively affect ash growth in the future. Previous research on ash stands in Latvia showed lower soil reaction for damaged or infected trees with fungus Hymenoscyphus fraxinea, compared with the background level in soil below undamaged trees. Notably, the observed mean soil reaction for soil around damaged trees $(5.23 \pm$ $0.73 \mathrm{pH} / \mathrm{KCl}$ ) was close to the lowest value suitable for $F$. excelsior (Cekstere et al., 2013). Perhaps, soil reaction might limit mature ash tree growth and mineral nutrition in the future. A study in Switzerland demonstrated no distribution limit of regenerating ash with soil acidity, but the growth potential was limited for mature ash (Walthert et al., 2013).

An important factor affecting plant mineral nutrition is element concentration ratios, particularly the $\mathrm{Ca}$ and $\mathrm{Mg}$ ratio in soil. The most optimal Ca: $\mathrm{Mg}$ ratio in soils using $1 \mathrm{M}$ $\mathrm{HCl}$ extract for plant nutrition is 5-8:1 (Rinkis and Nollendorfs, 1982). The average Ca:Mg ratio in the ash soil in Latvia corresponded to the suitable range, but had a large range and in some cases was not favourable for $\mathrm{Ca}$ and $\mathrm{Mg}$ uptake from the soil, due to differences in soil texture and parent material. Soils in Latvia have developed on different parent or geological material (Kasparinskis, 2012). Soils on dolomites usually have a very low $\mathrm{Ca}: \mathrm{Mg}$ ratio, e.g., site \#28 Ca:Mg=1.30, but on limestone — very high, e.g., site \#10 Ca:Mg = 14.70. Also sites \#26 and 27 had shallow dolomite deposits or parent material, which resulted in higher concentrations of $\mathrm{Ca}$ and $\mathrm{Mg}$ in the soil and $\mathrm{pH}$. There are reports that ash can grow and dominate also on relatively dry calcareous sites in central Europe and at the northern limit of its natural distribution (Wardle, 1959; Ellenberg, 1996) as in Latvia, probably due to lack of competition from other species (Dobrowolska et al., 2011).

The observed associations between the chemical parameters in the soils might be related with soil texture, parent mate-
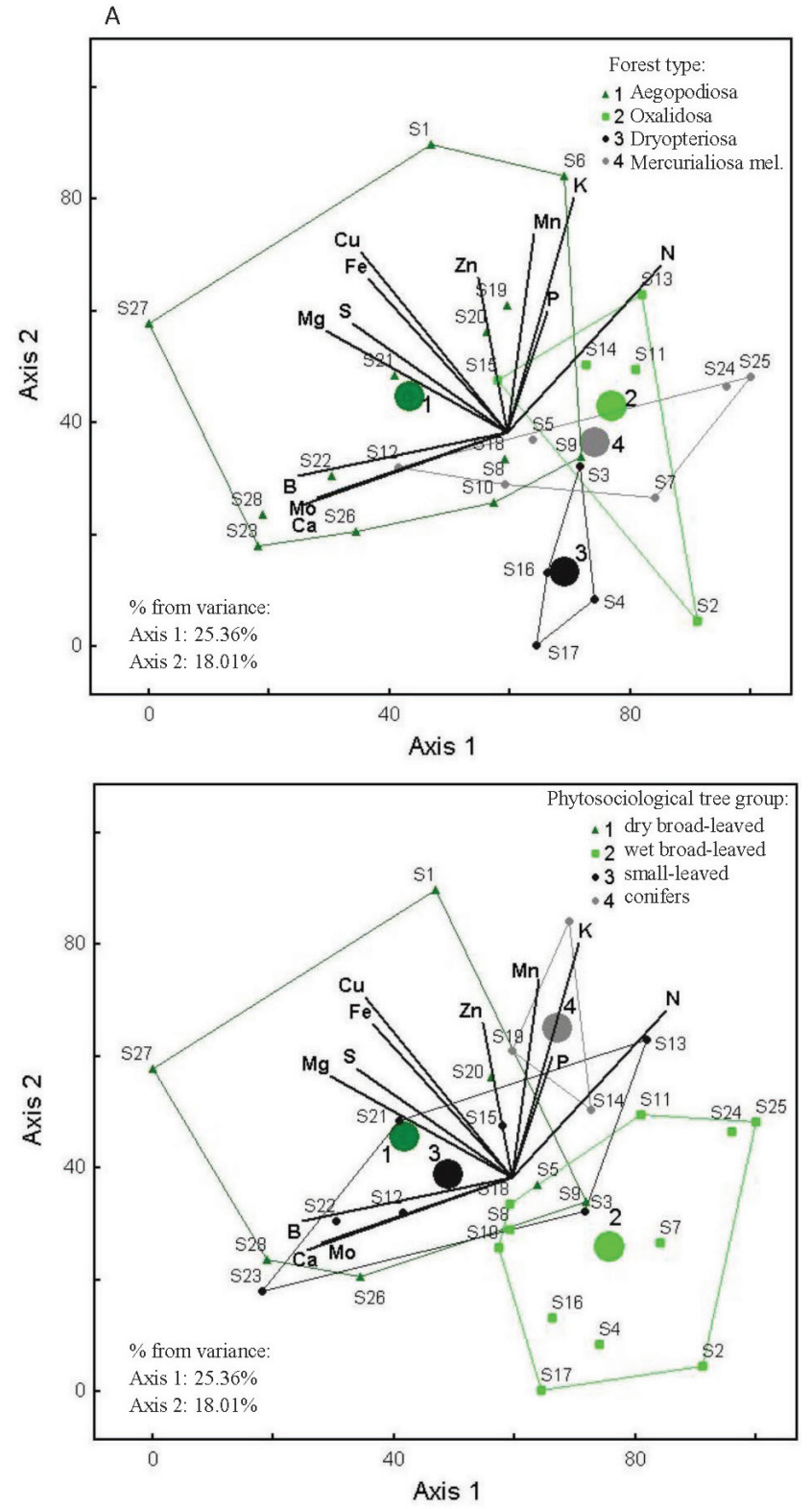

Fig. 6. Principal component analysis of chemical composition of healthy ash leaves in Latvia.

rial, geological deposits, accumulation of organic matter, etc. Similar observations on the relationship of soil texture and parent material with concentration of chemical elements have been found in previous studies on forest soils in Latvia (Gilucis, 2007; Bārdule et al., 2009; Kasparinskis, 2012; Kasparinskis and Nikodemus, 2012; Laiviňš et al., 2014; etc.), as well as in Europe (Vanmechelen et al., 1997, Holzwarth et al., 2011).

Mineral soils with young ash had significantly lower level of plant available N, S, Fe, and B compared with other soil groups, mainly due to lower content of organic matter. The organic matter concentrated in the topsoil can be considered as the main reservoir for plant available N, P, S, B and other nutrients (Marschner, 1995). Differences between the soils from various forest types found in our study were mainly related with content of $\mathrm{N}, \mathrm{Cu}$, and $\mathrm{B}$. Such differences could 
be caused not only by soil physical and chemical characteristics, but also depend on the effect of different tree species. Tree species can affect soil chemical properties, especially topsoil, via features of leaf/needle litterfall, interception of atmospheric depositions by the crown, variation in the amount and distribution of throughfall, as well as by the ability of various tree species to uptake and redistribute nutrients (Binkley and Valentine, 1991; Neirynck et al., 2000; Augusto et al., 2002; Reich et al., 2005; Guckland et al., 2009; Holzwarth et al., 2011; Kasparinskis, 2012; Langenbruch et al., 2012).

The results indicate that young ash can grow well in the highly heterogeneous soils in terms of nutrient and soil organic matter concentration, as well as soil reaction. On average, ash tree soils in Latvia can provide sufficient supply of nutrients for deciduous trees. However, deficiencies of $\mathrm{N}$, $\mathrm{P}, \mathrm{Ca}, \mathrm{Fe}$, or B were found for some study sites. Significant impact of soil group and forest type on the nutrient composition of soil below healthy young ash was observed.

Leaves. In general, the observed mean concentrations of most of the macronutrients in the ash leaves corresponded well with the mean concentrations reported for $F$. excelsior leaves in various countries: $\mathrm{N}>2.00 \%, \mathrm{P}>0.15 \%, \mathrm{Ca}>$ $1.50 \%, \mathrm{Mg}>0.35 \%, \mathrm{~S}>0.23 \%$, or could be characterized as limiting for $\mathrm{K}$ (reported $\mathrm{K}>1.2 \%$ ) (Niinements and Kull 2003; Hagen-Thorn et al., 2004, Hofmeister et al., 2004; Veretennikov, 2006). Among micronutrients, the found mean concentrations of $\mathrm{Mn}$ in young ash leaves for $\mathrm{Zn}, \mathrm{Cu}$, and $\mathrm{B}$ were about the same level or slightly low than previously reported (Hagen-Thorn et al., 2005): $\mathrm{Mn}>55, \mathrm{Zn}>$ $19, \mathrm{Cu}>9$, and $\mathrm{B}>26 \mathrm{mg} / \mathrm{kg}$. The differences in nutrient uptake might be due to a vast range of factors: regional variation, sampling time, soil conditions, e.g. formation of poorly soluble compounds in the neutral - slightly acid soil reaction, element antagonism, differences in mycorrhizal activity, and soil organic matter content, all of which influence the availability of nutrients in the soil and the uptake by plants. Unfortunately, in the scientific literature there are no reports on all 12 plant nutrients analysed in the same study site and time. Therefore, the comparison and interpretation of the results is complicated. On the other hand, the complex data obtained in this study on nutrient status of ash tree will be of great value for future studies.

In general, the results on chemical composition of ash leaves showed sufficient supply with most nutrients, excepting $\mathrm{P}, \mathrm{Zn}$, and $\mathrm{K}$. Plant available $\mathrm{K}$ in soil usually does not form insoluble compounds, and therefore the low level in leaves might be due to insufficient or low plant available $\mathrm{K}$ levels in soil, element antagonism, or leaf age (sampling was conducted in August). Concentration of $\mathrm{K}$ in leaves decreases during vegetation season due to reutilization and retranslocation in plants (Marschner, 1995). In slightly acid to neutral $\mathrm{pH}$ soils, typical for ash stands in Latvia, competition from $\mathrm{Ca}$ and $\mathrm{Mg}$ can seriously reduce uptake of $\mathrm{K}$.

The reduced concentrations of $\mathrm{P}, \mathrm{Zn}$, as well as in some sites low levels of $\mathrm{Cu}, \mathrm{Fe}$ and $\mathrm{Mn}$, and $\mathrm{B}$ in leaves can be explained by formation of poorly soluble compounds in the neutral — slightly alkaline soil, element antagonism, as well as high content of organic matter in growing media. There were several significant negative correlations between the nutrient content in the soil and leaves, two of which have been already reported for ash in Latvia: Ca-Mn, $\mathrm{Fe}-\mathrm{Cu}$ (Cekstere et al., 2013). Neutral and alkaline soil reaction promotes oxidation of $\mathrm{Mn}^{+2}$ into $\mathrm{Mn}^{+4}$, which is less available for plants (Bergmann, 1988). In alkaline soil Mn can form anion complexes and complexes with organic ligands, which are available to plants (Polevoi, 1989), but this is not sufficient for optimal tree uptake. As a result, the ash leaves in some sites contained only $20 \mathrm{mg} \cdot \mathrm{kg}^{-1} \mathrm{Mn}$. It is well known that organic matter is a source of $\mathrm{Zn}$ in soil, and organic compounds can chelate inorganic sources of $\mathrm{Zn}$ increasing their availability for plant uptake (Szabo et al., 2008). Therefore, $\mathrm{Zn}$ deficiency for plants is more characteristic in mineral soils with low organic content. An opposite phenomenon is typical for $\mathrm{Cu}$ uptake - copper is readily and tightly complexed by organic matter (Marschner, 1995). Our results were not consistent with these results.

The decreased level of any essential nutrient can seriously disturb plant physiological processes. In general, $\mathrm{Zn}$ and $\mathrm{Cu}$ affect mechanisms responsible for plant tolerance and resistance to fungus and bacterial diseases (Marschner, 1995). Studies have shown that fungal infection primarily takes place through the leaves of $F$. excelsior via ascospores (Timmermann et al., 2011). Therefore, optimal supply with nutrients is very important factor in conditions of infection pressure and unfavourable environmental conditions.

There were few significant correlations between the element concentration in the soil and plants, as shown previously (Roper, 1992). Studies in southern Swedish beech forests have shown that soil alone did not account for the major part of the variation in leaf nutrient concentrations (Alrikson and Eriksson, 1998). Similar results were also demonstrated in our research. The exception was for B and $\mathrm{Ca}$. Significant correlation between amount of $\mathrm{Ca}$ in soil and tree leaves was found both in the previous study on ash in Latvia (Cekstere et al., 2013) and on beech in Sweden (Balsberg-Påhlsson, 1989). Leaf analyses provide an accurate picture of the nutrient status of ash in Latvia at a particular point in time resulting from all factors affecting plant growth. It should be stressed that soil testing is very important in detecting the character and reasons of nutrient deficiencies or toxicities in plants. Typically, Mo availability for plant uptake increases with soil $\mathrm{pH}$. In our study, this phenomenon was confirmed by the positive correlation association between $\mathrm{Ca}, \mathrm{Mg}$ content in soil, soil reaction and Mo content in ash leaves. The observed positive moderately close correlation between $\mathrm{Ca}-\mathrm{Mg}$ in ash leaves, as well as in the soil was in a good agreement with the results on ash previously reported by Cekstere et al. (2013) in Latvia.

Ash in Aegopodiosa type forests grow on mineral soils, which have the lowest level of $\mathrm{S}$ in comparison with humus or mineral/humus soils. Thus indicates that on the one hand 
the amount of plant available $\mathrm{S}$ in mineral soil was sufficient for tree uptake, while on the other hand - there was stronger element antagonism in humus and mineral/humus soils, which decreased S uptake in ash leaves. There might also be significant impact of soil conditions like temperature, moisture, and drainage, which affect microbial dependent organic $S$ conversion to plant available sulphates. As $S$ is available for plant uptake as an anion, its antagonists are $\mathrm{N}$ and $\mathrm{B}$, which can reduce $\mathrm{S}$ accumulation in leaves. It is not surprising that a significantly lower content of $\mathrm{Cu}$ in young ash leaves was found in Dryopteriosa type forests on organic soils. $\mathrm{Cu}$ has a strong affinity to soil organic matter compared with other divalent cations in the order of $\mathrm{Cu}>\mathrm{Ca}>\mathrm{Zn}>\mathrm{Mn}>\mathrm{Mg}$ (Mengel et al., 2001). Although there were differences between the concentrations of $\mathrm{Mo}, \mathrm{Mg}$, and $\mathrm{Zn}$ in ash leaves collected in various phytosociological tree groups, ash leaves from all these groups had on average optimal supply with $\mathrm{Mg}$ and Mo, according to values reported by Nollendorfs (unpublished) and Bergmann (1988).

In general, the results of our study demonstrated relatively sufficient nutrient levels in leaves of young ash growing on heterogeneous and not always nutrient-rich soils, indicating accumulation of nutrients in plants during the whole vegetation season, plant physiologically active impact on nutrient uptake processes, as well as a rapid nutrient cycling in the system "soil-plants". Studies on different tree species in UK showed that $F$. excelsior had more rapid and complete cycling of nutrients without accumulation in the litter layer than many other deciduous species (Mitchell et al., 2014).

Based on the present work, it can be concluded that young ash in Latvia grows well on a wide range of site types in terms of soil composition, forest type and phytosociological tree group. Although highly heterogeneous, ash tree soils in Latvia can provide sufficient supply of nutrients for ash trees. Nutrient status of healthy young ash leaves can be characterised as sufficient, although low level of $\mathrm{P}, \mathrm{Zn}$, and $\mathrm{K}$ in leaves was found for the majority of sites. Significant impact of soil group and forest type was found on nutrient composition of ash soil, while leaf nutrient concentrations were more dependent on forest type and phytosociological tree group. The obtained results confirmed the ability of ash to accumulate nutrients within a certain range from soils of different fertility, organic matter content and soil reaction in Latvia.

\section{ACKNOWLEDGMENTS}

This study was carried out within the scope of Latvian State Forest project "Ash forest destruction and regeneration in Latvia” (No 5.5.-5.1_0017_101_14_28) and by the Forest Sector Competence Centre project "Methods and technologies for increasing forest capital value" (No L-KC-110004)". The authors are grateful to Ilze Pušpure for technical help in preparation of the cartographical material of the research sites.

\section{REFERENCES}

Aksoy, A., Demirezen, D. (2006). Fraxinus excelsior as a biomonitor of heavy metal pollution. Pol. J. Environ. Stud., 15 (1), 27-33.

Alriksson, A., Eriksson, H. M. (1998). Variation in mineral nutrient and C distribution in the soil and vegetation compartments of five temperate tree species in NE Sweden. For. Ecol. Manag., 108, 261-273.

Augusto, L., Ranger, J., Binkley, D., Rothe, A. (2002). Impact of several common tree species of European temperate forests on soil fertility. Ann. For. Sci., 59, 233-253.

Balsberg-Påhlsson, A. M. (1989). Mineral nutrients, carbohydrates and phenolic compounds in leaves of beech (Fagus sylvatica L.) in southern Sweden as related to environmental factors. Tree Physiol., 5, 485-495.

Bambergs, K., Knāviṇa, M. (1950). Minerālvielu un mikroelementu saturs veselos un trupējošos kokos [Mineral substance and microelement content in healthy and decayed trees]. Latvijas PSR ZA Vēstis [Proceedings of the LAS], 8, 21-30.

Bārdule, A., Bāders, E., Stola, L., Lazdiṇš, A. (2009). Forest soil characteristic in Latvia according results of the demonstration project BioSoil. Mežzinātne/ Forest Science, 20 (53), 105-124.

Bergmann, W. (1988). Ernährungsstörungen bei Kulturpflanzen. Gustav Fischer Verlag, Jena. $762 \mathrm{~S}$.

Binkley, D., Valentine, D. (1991). Fifty-year biogeochemical effects of green ash, white pine, and Norway spruce in a replicated experiment. For. Ecol. Manag., 40, 13-25.

Bušs, K. (1981). Meža ekologija un tipologija [Forest Ecology and Typology]. Zinātne, Rīga. 64 lpp. (in Latvian).

Cekstere, G., Laiviňš, M., Osvalde, A. (2013). Destruction of young Fraxinus excelsior stands and mineral nutritions status in Latvia, a pilot study. Acta Biol. Univ. Daugavp., 13 (1), 31-43.

Craul, P. J. (1999). Urban Soils. Applications and Practices. John Wiley and Sons, New York. 377 pp.

Daugaviete, M., Korica, A.M., Silins, I., Barsevskis, A., Bardulis, A., Bardule, A., Spalvis, K., Daugavietis, M. (2015). The use of mineral nutrients for biomass production by young birch stands and stands vitality in different forest growing conditions. J. Environ. Sci. Eng., B, 4, 177-189.

Diekmann, M. (1996). Ecological behaviour of deciduous hardwood trees in Boreo-nemoral Sweden in relation to light and soil conditions. For. Ecol. Manag., 86, 1-14.

Dobrowolska, D., Hein, S., Oosterbaan, A., Wagner, S., Clark, J., Skovsgaard, J. P. (2011). A review of European ash (Fraxinus excelsior L.): Implications for silviculture. Forestry, 84, 133-148.

Ellenberg, H. (1996). Vegetation Mitteleuropas mit den Alpen. $5^{\text {th }}$ edn. Ulmer, Stuttgart, 1096 pp.

Fraxigen (2005). Ash Species in Europe: Biological Characteristics and Practical Guidelines for Sustainable Use. University of Oxford, Oxford. $125 \mathrm{pp}$.

Gilucis, A. (2007). Mikro- un makroelementu satura izplatības likumsakarības Latvijas augšnu virsējos horizontos [Relevance of Content and Distribution of Trace and Major Elements in the Latvian Topsoils]. Summary of Doctoral Thesis. LU Akadēmiskais apgāds, Rīga. 29 pp.

Gross, A. (2014). Hymenoscyphus pseudoalbidus, the causal agent of European ash dieback. Mol. Plant Pathol., 15 (1), 5-21.

Guckland, A., Jacob., M., Flessa, H., Thomas, F.M., Leuschner, C. (2009). Acidity, nutrient stocks, and organic-matter content in soils of a temperate deciduous forest with different abundance of European beech (Fagus sylvatica L.). J. Plant Nutr. Soil Sci., 172, 500-511.

Hagen-Thorn, A., Armolaitis, K., Callesen, I., Stjernquist, I. (2004). Macronutrients in tree stems and foliage: A comparative study of six temperate forest species planted at the same sites. Ann. For. Sci., 61, 489-498.

Hagen-Thorn, A., Sthernquist, L. (2005). Micronutrient levels in some temperate European tree species: A comparative field study. Trees, 19, 592-579. 
Hofmeister, A., Mihaljevič, M., Hošek, J. (2004). The spread of ash (Fraxinus excelsior) in some European oak forests: an effect of nitrogen deposition or successional change? For. Ecol. Manag. 203, 35-47.

Holzwarth, F. M., Daenner, M., Flessa, H. (2011). Effects of beech and ash on small-scale variation of soil acidity and nutrient stocks in a mixed deciduous forest. J. Plant Nutr. Soil Sci., 174, 799-808.

Jankovsky, L., Holdenrieder, O. (2009). Chalara fraxinea - ash dieback in the Czech Republic. Plant Protect. Sci., 45, 74-78.

Janševska, Z. (1975). Egḷu skuju ķīmiskā sastāva izmaiṇas augsnē nosusināšanas iespaidā [Changes in chemical composition of spruce needles due to drainage]. Jaunākais Mežsaimniecībā, 18, 60-63 (in Latvian).

Kāposts, V., Sacenieks, R., Janševska, Z. (1979). Minerālmēslojuma izmantošana priežu kultūrās [Application of mineral fertilizers for pines]. Jaunākais Mežsaimniecībā, 21, 55-60 (in Latvian).

Kasparinskis, R. (2012). Latvijas meža augšṇu daudzveidība un to ietekmējošie faktori [Diversity of Forest Soils and Its Influencing Factors in Latvia]. Doctoral Thesis. LU Akadēmiskais apgāds, Rīga. 154 pp (in Latvian).

Kasparinskis, R., Nikodemus, O. (2012). Influence of environmental factors on the spatial distribution and diversity of forest soil in Latvia. Est. J. Earth Sci., 61 (1), 48-64.

Kenigsvalde, K., Arhipova, N., Laiviņ̌̌, M., Gaitnieks, T. (2010). Ošu audžu bojāeju izraisošā sēne Chalara fraxinea Latvijā [Fungus Chalara fraxinea as a causal agent for ash decline in Latvia]. Mežzinātne/ Forest Science, 21, 110-120 (in Latvian)

Kerr, G., Cahalan, C. (2004). A review of site factors affecting the early growth of ash (Fraxinus excelsior L.). For. Ecol. Manag., 188, 225-234.

Keßler, M., Cech, T.L., Brandstetter, M., Kirisits, T. (2012). Dieback of ash (Fraxinus excelsior and Fraxinus angustifolia) in Eastern Austria: Disease development on monitoring plots from 2007 to 2010. J. Agr. Ext. Rural Dev., 4 (9), 223-226.

Kirisits, T., Freinschlag, C. (2012). Ash dieback caused by Hymenoscyphus pseudoalbidus in a seed plantation of Fraxinus excelsior in Austria. J. Agr. Ext. Rural Dev., 4, 184-191.

Klavina, D. (2015). Ectomycorrhizas of Norway spruce (Picea Abies (L.) Karst.) in managed forest stands of Latvia. Summary of Doctoral Thesis. University of Latvia, Latvian State Forest Research Institute "Silava", $36 \mathrm{pp}$.

Kowalski, T. (2006). Chalara fraxinea sp. nov. associated with dieback of ash (Fraxinus excelsior) in Poland. Forest. Pathol., 36, 464-470.

Laiviňš, M., Čekstere, G., Medene, A., Donis, J. (2014). Structure and dynamics of oligomesic dry pine forests in land zones of the Lake Engure catchment's area. Proc. Latvian Acad. Sci., Section B, 68 (1/2), 80-92.

Laiviňš, M., Priede, A., Pušpure, I., Gerra-Inohosa, L. (2016). Changes of young ash stands area in Latvia and invasion of Hymenoscyphus fraxineus. Proc. Latvian Acad. Sci., Section B, 70 (3), 124-130.

Langenbruch, C., Helfrich, M., Flessa, H. (2012). Effects of beech (Fagus sylvatica), ash (Fraxinus excelsior) and lime (Tilia spec.) on soil chemical properties in a mixed deciduous forest. Plant Soil, 352, 389-403.

Mandre, M., Klõšeiko, J., Lukjanova, A., Tullus, A. (2012). Hybrid aspens responses to alkalization of soil: Growth, leaf structure, photosynthetic rate and carbohydrates. Trees, 26 (6), 1847-1858.

Marschner, H. (1995). Mineral Nutrition of Higher Plants. $2^{\text {nd }}$ edn. Academic Press, Cambridge. 889 pp.

McCune, B., Mefford, M. J. (1999). PC-ORD. Multivariate Analysis of Ecological Data, Version 4. MjM Software Design, Oregon. 28 pp.

Mengel, K., Kirkby, E.A., Kosegarten, H., Appel. T. (2001). Principles of Plant Nutrition. 5th edn. Kluwer Academic Publishers, Dordrecht. 849 pp.

Mertens, J., Van Nevel, L., De Schrijver, A., Piesschaert, F., Oosterbaan, A., Tack, F. M. G., Verheyen, K. (2007). Tree species effect on the redistribution of soil metals. Environ. Pollut., 149, 173-181.
Mitchell, R. J., Beaton, J. K., Bellamy, P. E., Broome, A., Chetcuti, J., Eaton, S., Ellis, C. J., Gimona, A., Harmer, R., Hester, A. J., Hewison, R. L., Hodgetts, N. G., Iason, G. R., Kerr, G., Littlewood, N.A., Newey, S., Potts, J. M., Pozsgai, G., Ray, D., Sim, D. A., Stockan, J. A., Taylor, A. F. S., Woodward, S. (2014). Ash dieback in the UK: A review of the ecological and conservation implications and potential management options. Biol. Conserv., 175, 95-109.

Neirynck, J., Mirtcheva, S., Sioen, G., Lust, N. (2000). Impact of Tilia platyphyllos Scop., Fraxinus excelsior L., Acer pseudoplatanus L., Quercus robur L. and Fagus sylvatica L. on earthworm biomass and physico-chemical properties of a loamy topsoil. For. Ecol. Manag., 133, 275-286.

Niinements, Ü., Kull, K. (2005). Co-limitation of plant primary productivity by nitrogen and phosphorus in a species-rich wooded meadow on calcareous soils. Acta Oecol., 28, 345-356.

Osvalde, A. (1996). Heavy Metals — Pb, Hg, Ni, V, Sn — in Biological Objects of Latvia, Lowering of Their Toxicity by Regulating Plant Nutrition. Summary of PhD Thesis, University of Latvia, Riga. 44 pp.

Osvalde, A. (2011). Optimization of plant mineral nutrition revisited: The roles of plant requirements, nutrient interactions, and soil properties in fertilization management. Environ. Exper. Biol., 9, 1-8.

Osvalde, A., Karlsons, A. (2010). Evaluation of the American cranberry nutrient status in Latvia during 2001-2007. Acta Horticult., 868, 213-218.

Osvalde, A., Pormale, P., Karlsons, A., Cekstere, G. (2015). Differences in agrochemical characteristics of highbush blueberry peat and mineral soils in Latvia, 2011-2014. In: $15^{\text {th }}$ International Multidisciplinary Scientific Geoconference SGEM, 18-24 June 2015, Albena, Bulgaria. Conference proceedings, Volume II. Water Resources. For. Mar. Ocean Ecosyst., 101-108.

Pautasso, M., Aas, G., Queloz, V., Holdenrieder, O. (2013). European ash (Fraxinus excelsior) dieback: A conservation biology challenge. Biol. Conserv., 158, 37-49.

Pliura, A., Heuertz, M. (2003). EUFORGEN Technical Guidelines for Genetic Conservation and Use for Common Ash (Fraxinus excelsior). International Plant Genetic Resources Institute, Rome, Italy. 6 pp.

Pliūra, A., Lygis, V., Suchockas, V., Bartkevičius, E. (2011). Performance of twenty four European Fraxinus excelsior populations in three Lithuanian progeny trials with a special emphasis on resistance to Chalara fraxinea. Baltic For., 17 (1), 17-34.

Polevoi, V. V. (1989). Plant physiology [Полевой, В.В. Физиология растений]. Vysshaya shkola, Moscow. 464 pp. (in Russian).

Reich, P. B., Oleksyn, J., Modrzynski, J., Mrozinski, P., Hobbie, S. E., Eissenstat, D. M., Chorover, J., Chadwick, O. A., Hale, C. M., Tjoelker, M G. (2005). Linking litter calcium, earthworms and soil properties: A common garden test with 14 tree species. Ecol. Letters, 8, 811-818.

Riņkis, G., Ramane, H. (1989). Kā barojas augi [Plant Nutrition]. Avots, Rīga. 151 pp. (in Latvian).

Rinkis, G., Ramane, H., Kunicka, T. (1987). Methods of Soil and Plant Analysis [Ринькис Г. Я., Рамане Х. К., Куницкая Т. А. Методы анализа поче и растений]. Zinatne, Riga. 174 pp. (in Russian).

Rinkis, G. J., Nollendorfs, V. F. (1982) Optimal Plant Supply with Macroand Microelements [Ринькис Г. Я., Ноллендорф В. Ф. Сбалансированное питание растений макро- и микроэлементами]. Zinatne, Riga. 202 pp. (in Russian).

Rytkönen, A., Lilja, A., Drenkhan, R., Gaitnieks, T., Hantula, J. (2011). First record of Chalara fraxinea in Finland and genetic variation among isolates sampled from Åland, mainland Finland, Estonia and Latvia. For. Pathol. 41 (3), 169-174.

Timmermann, V., Børja, I., Hietala, A.M., Kirisits, T., Solheim, H. (2011). Ash dieback: Pathogen spread and diurnal patterns of ascospore dispersal, with special emphasis on Norway. European and Mediterranean Plant Protection Organization (EPPO) Bulletin, 40, 14-20. 
Vanmechelen, L., Groenemans, R., Van Rast, E. (1997). Forest Soil Condition in Europe. Results of a Large-scale Soil Survey. 1997 Technical Report. EC, UN/ECE, Ministry of the Flemish Community, Brussels, Geneva. $259 \mathrm{pp}$.

Veretennikov, A. V. (2006). Plant physiology [Веретенников А. В. Физиология растений]. Akademichesky prospekt, Moscow. 480 pp. (in Russian).
Walthert, L., Graf Pannatier, E., Meier, E. S. (2013). Shortage of nutrients and excess of toxic elements in soils limit the distribution of soil-sensitive tree species in temperate forests. For. Ecol. Manag., 297, 94-107.

Wardle, P. (1959). The regeneration of Fraxinus in woods with a layer of Mercurialis perennis. J. Ecol., 47, 483-497.

Zollner, A., Kölling, C. (1994). Eschenkulturen auf ungeeigneten Standorten. Allg. Forstz., 2, 61-64 (in German).

Received 8 March 2016

\section{JAUNO OŠU MINERĀLĀS BAROŠANĀS NODROŠINĀJUMS LATVIJĀ}

Pētījums veikts, lai noskaidrotu veselīgi augošu jauno ošu apgādi ar barības elementiem un to koncentrāciju variāciju dabiskos augšanas apstākḷıs, lai izvērtētu barības elementu balansu un sakarības sistēmā "augsne-augs", kā arī lai skaidrotu vides faktoru (meža tips, augu fitosocioloğiskā grupa, augsnes grupa, u.c.) ietekmi uz barības elementu akumulāciju jauno ošu augsnē un lapās. Ošu paaugas lapu un augsnes paraugi ievākti 28 dažādās mežaudzēs atškirīgos dabas reǵionos Latvijā. Rezultāti parādīja, ka jaunie oši var veiksmīgi augt ḷoti atškirīīgās vietās gan augsnes sastāva, meža tipa, gan fitosocioloğiskā ziṇā. Tādējādi ḷoti heterogēnie augsnes apstākḷi spēja nodrošināt visumā pietiekamu jauno ošu apgādi ar barības elementiem; kā izṇēmums minams pazemināts $\mathrm{P}$, Zn un K nodrošinājums koku lapās vairākās pētījuma vietās. Tika konstatēta būtiska augsnes grupas un meža tipa ietekme uz augsnes kịmisko sastāvu, savukārt elementu uzkrāšanos lapās būtiski ietekmēja meža tips un fitosocioloǵiskā koku grupa. 